\title{
Soil Fertility Status in Tatrakallu Village of Andhra Pradesh for Site Specific Recommendations
}

\author{
G. Sashikala ${ }^{1 *}$, M.V.S Naidu ${ }^{1}$, K.V Ramana ${ }^{2}$, K.V. Nagamadhuri ${ }^{1}$, \\ A. Pratap Kumar Reddy ${ }^{3}$ and P. Sushakar ${ }^{1}$
}

${ }^{1}$ Department of Soil Science and Agricultural Chemistry, S.V. Agricultural College, Acharya N.G. Ranga Agricultural University, Tirupati - 517 502, Andhra Pradesh, India

${ }^{2}$ Andhra Pradesh Space Applications Centre, Vijayawada, Andhra Pradesh, India

${ }^{4}$ Department of Agronomy, ARS, Utukur, Andhra Pradesh, India

*Corresponding author

\section{Keywords}

Soil fertility status, Grid method, Arc GIS, Tatrakallu village, Soil fertility constraints

\section{Article Info}

Accepted:

10 May 2019

Available Online:

10 June 2019

\section{A B S T R A C T}

Two hundred fifty soil samples from Tatrakallu village in scarce rainfall zone of Andhra Pradesh were drawn at $250 \mathrm{~m}$ grid interval leaving hills and water bodies and assessed for their fertility parameters. Analytical data was interpreted and statistical parameters like range, mean, standard deviation and coefficient of variation were calculated. Soil fertility maps were prepared for each parameter under GIS environment using Arc GIS v 10.3. Soils were neutral to strongly alkaline with non-saline in nature and soil organic carbon content was low to medium. The available nitrogen $(\mathrm{N})$ was low to medium, available phosphorus (P) and potassium (K) was low to high and available sulphur (S) was deficient to sufficient. Regarding available micronutrients, zinc $(\mathrm{Zn})$ and iron (Fe) were deficient to sufficient whereas, available copper $(\mathrm{Cu})$ and manganese $(\mathrm{Mn})$ was almost sufficient in the soils. The fertility status of nutrients in watershed revealed that, available N, S, Zn and Fe are important soil fertility constraints.

\section{Introduction}

Soil - a nature's marvel is one among the vital natural resources of the earth, on whose health, the survival of all living organisms depends. The soil must be in harmony with its inborn attributes and productivity to maintain sustainable soil health. Increasing population and escalating needs for food, carrying capacity of the soil is exploited in unshamed manner and non- sustainable land use shift has increased. These developments caused decline in native soil health and production potential of soil. According to UNCCD
(2011), every minute 10 ha of land is lost by degradation processes like erosion, nutrient depletion, salinity, acidity and compaction. The International Food Policy Research Institute (IFPRI, 2011) assessed that about 1 out of 4 ha of total global land area (14.8 B ha) has been affected by harmful acts of man. The share of India in global degraded soil area is about $10 \%$. Anantapuramu is the largest district of Andhra Pradesh and second driest part of the country after Jaisalmer in Rajasthan. The district of Anantpuramu is chronically drought-affected especially, Vajrakarur mandal and in particular 
Tatrakallu village. The Tatrakallu village in Anantapuramu district of Andhra Pradesh which is pre-dominantly under rainfed farming with erratic rainfall distribution associated with low crop productivity and needs site-specific information in terms of soil characteristics, their productivity potentials and limitations for soil resource development and management. Hence, the present investigation was planned and executed with the objective of identifying available nutrient constraints in soils of Tatrakallu village in scarce rainfall zone of Andhra Pradesh.

\section{Materials and Methods}

The Tatrakallu village lies in between $14^{\circ} 58^{\prime}$ to $15^{\circ} 00^{\prime} \mathrm{N}$ latitudes and $77^{\circ} 19^{\prime}$ to $77^{\circ} 25^{\prime} \mathrm{E}$ longitudes with a spatial extent of 2469.29 ha. (Fig. 1). The soils in the village were developed from granite-gneiss and limestone. The climate of the village was semi-arid monsoonic with distinct summer, winter and rainy seasons. The mean annual rainfall recorded for the last 10 years (2009 to 2018) was $528.40 \mathrm{~mm}$ of which 96.33 percent was received during May to November. The mean annual temperature was $33.03{ }^{\circ} \mathrm{C}$ with mean summer temperature of $40.5^{\circ} \mathrm{C}$ and mean winter temperature of $26.13{ }^{\circ} \mathrm{C}$. The maximum temperature recorded for the last ten years was $38.4{ }^{\circ} \mathrm{C}$ and the minimum temperature was $17.2^{\circ} \mathrm{C}$ in the month of April and November, respectively. The soil moisture regime has been computed as ustic and soil temperature regime as iso hypertherrmic. The natural vegetation of the study area were Acacia nilotica, Borassus flabellifer, Tamarindus indica, Tephrosia purpurea, Parthenium hysterophorus, Azadirachta indica, Cassia auriculata, Calotropis gigantea, opuntia humifusa, Prosopis juliflora, Zizyphus jujube, Pongamia pinnata, Cactus spp.
Surface composite soil samples were collected using a handheld GPS on grid points of $250 \mathrm{~m}$ interval in the study area. A total of 250 samples were collected from the Tatrakallu village. The soil samples were airdried, ground $(<2 \mathrm{~mm})$ and analyzed for physico-chemical and fertility parameters. The $\mathrm{pH}(1: 2.5)$ and electrical conductivity (EC) $(1: 2.5)$ of soils were measured using standard procedures as described by Jackson (1973). Organic carbon (OC) was determined using the Walkley-Black method (Nelson and Sommers 1996). Available nitrogen (N) was estimated by alkaline permanganate method (Subbiah and Asija 1956). Available phosphorus (Olsen P) was measured using sodium bicarbonate $\left(\mathrm{NaHCO}_{3}\right)$ as an extractant (Olsen and Sommers 1982). Available potassium (K) was determined using the ammonium acetate method (Jackson, 1973). Available sulphur (S) was measured using 0.15 percent calcium chloride $\left(\mathrm{CaCl}_{2} \cdot 2 \mathrm{H}_{2} \mathrm{O}\right)$ as an extractant (Williams and Steinbergs, 1959). Micronutrients (Fe, $\mathrm{Zn}, \mathrm{Cu}$ and $\mathrm{Mn}$ ) were extracted by DTPA using the procedure outlined by Lindsay and Norvell (1978). Variability of data was assessed using mean standard deviation and coefficient of variation for each set of data. Availability of $\mathrm{N}, \mathrm{P}$ and $\mathrm{K}$ in soils are interpreted as low, medium and high and that of available sulphur $(\mathrm{S})$, zinc $(\mathrm{Zn})$, iron $(\mathrm{Fe})$, copper $(\mathrm{Cu})$ and manganese $(\mathrm{Mn})$ interpreted as deficient and sufficient by following the criteria given in table 1.

\section{Results and Discussion}

\section{Soil reaction and electrical conductivity}

Soils of the Tatrakallu village were neutral to strongly alkaline (6.49 to 8.90$)$ in reaction with a mean $\mathrm{pH}$ of 7.55 , standard deviation of 0.80 and coefficient of variation of 10.56 per cent. Higher soil reaction in the Tatrakallu village is mainly because of calcareous nature 
and sodicity of soils. The $\mathrm{CV}$ of soil $\mathrm{pH}$ indicates that spatially it did not vary. The lowest value of $\mathrm{pH}$ under the cultivated soils may be due to depletion of basic cations in crop harvest and drainage to streams in runoff by accelerated erosion. These results were in accordance with findings of Foth and Ellis (1997). The higher $\mathrm{pH}$ of soils could be attributed to calcareousness nature, sodicity, low intensity of leaching and accumulation of bases. These results were in agreement with findings of Patil et al., (2016) (Table 2). The EC of soils in Tatrakallu village was in the range of 0.01 to $0.84 \mathrm{dSm}^{-1}$ with a mean of $0.14 \mathrm{dSm}^{-1}$ and standard deviation of 0.13 . The coefficient of variation $(92.92 \%)$ of EC values indicated that salt content in Tatrakallu village varied spatially. Slightly higher level of soluble salts in the study area was due to semi-arid climatic condition. Soluble salt content in the study area revealed that, the study area was non-saline (Fig. 1). The values obtained in the present study were in agreement with those reported by Sathish et al., (2018) and Patil et al., (2016) in Alantha cluster villagea and Dindur sub-watershed of Karnataka, respectively.

\section{Organic carbon}

The soil organic carbon content (OC) of Tatrakallu village varied from 0.03 to 0.90 per cent with a mean and standard deviation values of 0.37 per cent and 0.15 , respectively. The CV of 39.95 per cent for organic carbon content indicated that, in the Tatrakallu village organic carbon varied spatially (Table 2). The reason for low organic carbon content in these soils may be attributed to the prevalence of semi-arid condition, where the degradation of organic matter occurs at a faster rate coupled with little or no addition of organic manures and low vegetation cover on the fields, there by leaving less chances of accumulation of organic carbon in the soils. Intensive cropping is also one of the Similar results were also reported by Prabhavati et al., (2015) and Nalina et al., (2016) for the soils of northern dry zone of Karnataka and soils of eastern dry zone of Karnataka.

\section{Available macronutrients}

The available nitrogen in surface soils of the Tatrakallu village varied from 13.00 to 326.00 $\mathrm{kg} \mathrm{ha}{ }^{-1}$ with a mean of 149.48 and SD of 70.42. The CV value of 47.11 per cent indicates that, available $\mathrm{N}$ in soils varied spatially (Table 2). The low available $\mathrm{N}$ could be attributed to soil management, varied application of FYM and fertilizers to previous crops. Another possible reason may also be due to low organic matter content in these areas due to low rainfall and high temperature which facilitate faster degradation and removal of organic matter leading to $\mathrm{N}$ deficiency. Similar N status was reported by Basavaraju et al., (2005), Shankaraiah et al., (2006) and Patil et al., (2016) in sandy loams and calcareous soils.

The available phosphorus content in soils of Tatrakallu village ranged from 2.00 to 512.00 $\mathrm{kg} \mathrm{P}_{2} \mathrm{O}_{5} \mathrm{ha}^{-1}$ with an average and SD values of 208.79 and 124.20, respectively. The CV of 59.33 per cent for available $\mathrm{P}_{2} \mathrm{O}_{5}$ distribution in the village indicates that, it varied spatially (Table 2). Semi-arid environment with low rainfall and continuous use of high analysis fertilizers especially DAP without knowing the crop requirement and soil availability in the study area resulting in the phosphorus build up and contributing towards high available phosphorus status in these soils. Kumar et al., (2002), Nalina et al., (2017) and Sathish et al., (2018) also found similar observations. The available potassium in surface soil samples of Tatrakallu village ranged from 0.37 to $628.05 \mathrm{~kg} \mathrm{~K} 2 \mathrm{O} \mathrm{ha}^{-1}$ with mean and SD values of 264.24 and 134.81, respectively. The $\mathrm{CV}$ of 51.02 for available potassium indicates that, it varied spatially in 
the study area (Table 2). Soils were able to maintain a sufficient or even high level of exchangeable $\mathrm{K}$ and provide a good supply of $\mathrm{K}$ to plants for many years. The medium to higher content of available $\mathrm{K} 2 \mathrm{O}$ in soils of Tatrakallu village may be due to the predominance of K-rich micaceous and feldspar minerals in parent material. Similar results were observed by Srikant et al., (2008).

The available $S$ in surface soil samples of Tatrakallu village varied from 0.12 to 50.11 $\mathrm{mg} \mathrm{kg}^{-1}$ soil with mean and SD values of 8.98 and 7.04, respectively. The CV of 78.43 per cent for available $\mathrm{S}$ indicates that, in the study area, available $S$ varied spatially (Table 2). The low available $S$ is partly due to gypsiferous nature of $\mathrm{S}$ which is nonavailable in black soils. Low and medium level of available $S$ was due to lack of sulphur addition, continuous removal of $\mathrm{S}$ by crops and use of high analysis complex fertilizers (Venkatesh and Satynarayana, 1999).

\section{Available micronutrients}

The available zinc in surface soil samples of Tatrakallu village varied from 0.05 to $5.60 \mathrm{mg}$ $\mathrm{kg}^{-1}$ with a mean and SD values of 0.57 and 0.64 , respectively. The CV of 113.07 per cent for available zinc indicates that, it varied spatially in the village (Table 3). The available $\mathrm{Zn}$ increased with decrease in $\mathrm{pH}$ and increase in organic carbon content. Similarly, Satyavathi and Reddy (2004) also reported that available $\mathrm{Zn}$ in soils decreased with increase in $\mathrm{pH}$. Since, most of the soils are alkaline, low in $\mathrm{OC}$ and dominated by $\mathrm{CaCO}_{3}, \mathrm{Zn}$ might have been precipitated as hydroxides and carbonates, as a result, their decreased solubility and mobility might have reduced the availability. Similar results were observed by Patil et al., (2016) and Satish et $a l$. , (2018) in soils of Dindur sub-watershed of
Karnataka and Brahmanakotkur watershed of Andhra Pradesh, respectively.

The available copper in surface soil samples of Tatrakallu village, ranged from 0.22 to $2.75 \mathrm{mg} \mathrm{kg}^{-1}$ with a mean and SD values of 0.68 and 0.38 , respectively. The CV value of 55.49 per cent for available copper indicates that, it varied spatially in the village (Table 3). Patil et al., (2016) also observed sufficient status of available copper in soils of north Karnataka. The available iron in surface soil samples of Tatrakallu village varied from 0.84 to $30.78 \mathrm{mg} \mathrm{kg}^{-1}$ with a mean and SD values of 4.60 and 4.24 , respectively. The CV of 92.06 per cent for available iron indicates that, it varied spatially in the village (Table 3). The low Fe content may be due to precipitation of $\mathrm{Fe}$ by $\mathrm{CaCO}_{3}$ which decreased its availability. Similar results were also observed by Patil et al., (2006) and Ravikumar et al., (2007). It was observed that the area is divided almost equally between sufficient and deficient in the study area, highlighting the importance of mapping the area rather than statistics derived from soil analysis.

The available manganese in surface soil samples of Tatrakallu village ranged from 1.38 to $39.00 \mathrm{mg} \mathrm{kg}^{-1}$ with a mean and SD of 9.23 and 8.41, respectively. The $\mathrm{CV}$ value of 91.11 per cent for available manganese indicates that, it varied spatially in the village (Table 3). Similar results were also reported by Reddy and Naidu (2013) who reported that available Mn was sufficient in the soils of Chennur mandal of YSR Kadapa district in Andhra Pradesh. Sufficient content of Mn was also observed by Ravikumar et al., (2007) in Vertisols of Malaprabha command area and Manojkumar (2011) in the soils of northern transition zone of Karnataka derived from basalt. 
Table.1 Soil fertility ratings for available nutrients

\begin{tabular}{|l|l|l|l|}
\hline Nutrients & \multicolumn{3}{|c|}{ Fertility rating of major nutrients } \\
\hline & Low & Medium & High \\
\hline Organic carbon (\%) & $<0.5$ & $0.5-0.75$ & $>0.75$ \\
\hline Macronutrients & & & \\
\hline Available nitrogen & 280 & $280-560$ & $>560$ \\
\hline Available $\mathbf{P}_{\mathbf{2}} \mathbf{O}_{\mathbf{5}}$ & $<22.9$ & $22.9-56.33$ & $>56.33$ \\
\hline Available $\mathbf{K}_{\mathbf{2}} \mathbf{O}$ & $<129.6$ & $129.6-336$ & $>336$ \\
\hline & Deficient & Sufficient & \\
\hline Available S & $<10$ & $>10$ & \\
\hline Micronutrients (mg kg-1 soil) & & & \\
\hline Zinc (Zn) & $<0.6$ & $>0.6$ & \\
\hline Copper $(\mathbf{C u})$ & $<0.2$ & $>0.2$ & \\
\hline Iron $($ Fe) & $<4.0$ & $>4.0$ & \\
\hline Managnese (Mn) & $<1.0$ & $>1.0$ & \\
\hline
\end{tabular}

Table.2 Physico-chemical properties and available major nutrients status in Tatrakallu village

\begin{tabular}{|c|c|c|c|c|c|c|c|}
\hline \multirow[t]{2}{*}{ Statistic } & \multicolumn{3}{|c|}{ Physico-chemical properties } & \multicolumn{4}{|c|}{ Available macronutrients ( $\left.\mathrm{kg} \mathrm{ha}^{-1}\right)$} \\
\hline & pH & $\mathrm{EC}\left(\mathrm{dS} \mathrm{m}^{-1}\right)$ & OC $(\%)$ & $\mathbf{N}$ & $\mathbf{P}_{2} \mathrm{O}_{5}$ & $\mathrm{~K}_{2} \mathrm{O}$ & $\mathrm{S}\left(\mathrm{mg} \mathrm{kg}^{-1}\right)$ \\
\hline Minimum & 6.49 & 0.01 & 0.03 & 13.00 & 2.00 & 0.37 & 0.12 \\
\hline Maximum & 8.90 & 0.84 & 0.90 & 326.00 & 512.00 & 628.05 & 50.11 \\
\hline Mean & 7.55 & 0.14 & 0.37 & 149.48 & 208.79 & 264.24 & 8.98 \\
\hline SD & 0.80 & 0.13 & 0.15 & 70.42 & 124.20 & 134.81 & 7.04 \\
\hline CV (\%) & 10.56 & 92.92 & 39.95 & 47.11 & 59.33 & 51.02 & 78.43 \\
\hline
\end{tabular}

Table.3 Available micronutrients status in Tatrakallu village

\begin{tabular}{|l|l|l|l|l|}
\hline \multicolumn{4}{|l}{ Available micronutrients $\left(\mathbf{m g ~ k g}^{-1}\right)$} & Mn \\
\hline Statistic & Zn & Cu & Fe & 1.38 \\
\hline Minimum & 0.05 & 0.22 & 0.84 & 39.00 \\
\hline Maximum & 5.60 & 2.75 & 30.78 & 9.23 \\
\hline Mean & 0.57 & 0.68 & 4.60 & 8.41 \\
\hline SD & 0.64 & 0.38 & 4.24 & 91.11 \\
\hline CV $(\%)$ & 113.07 & 55.49 & 92.06 & \\
\hline
\end{tabular}


Fig.1 Location map of Tatrakallu village

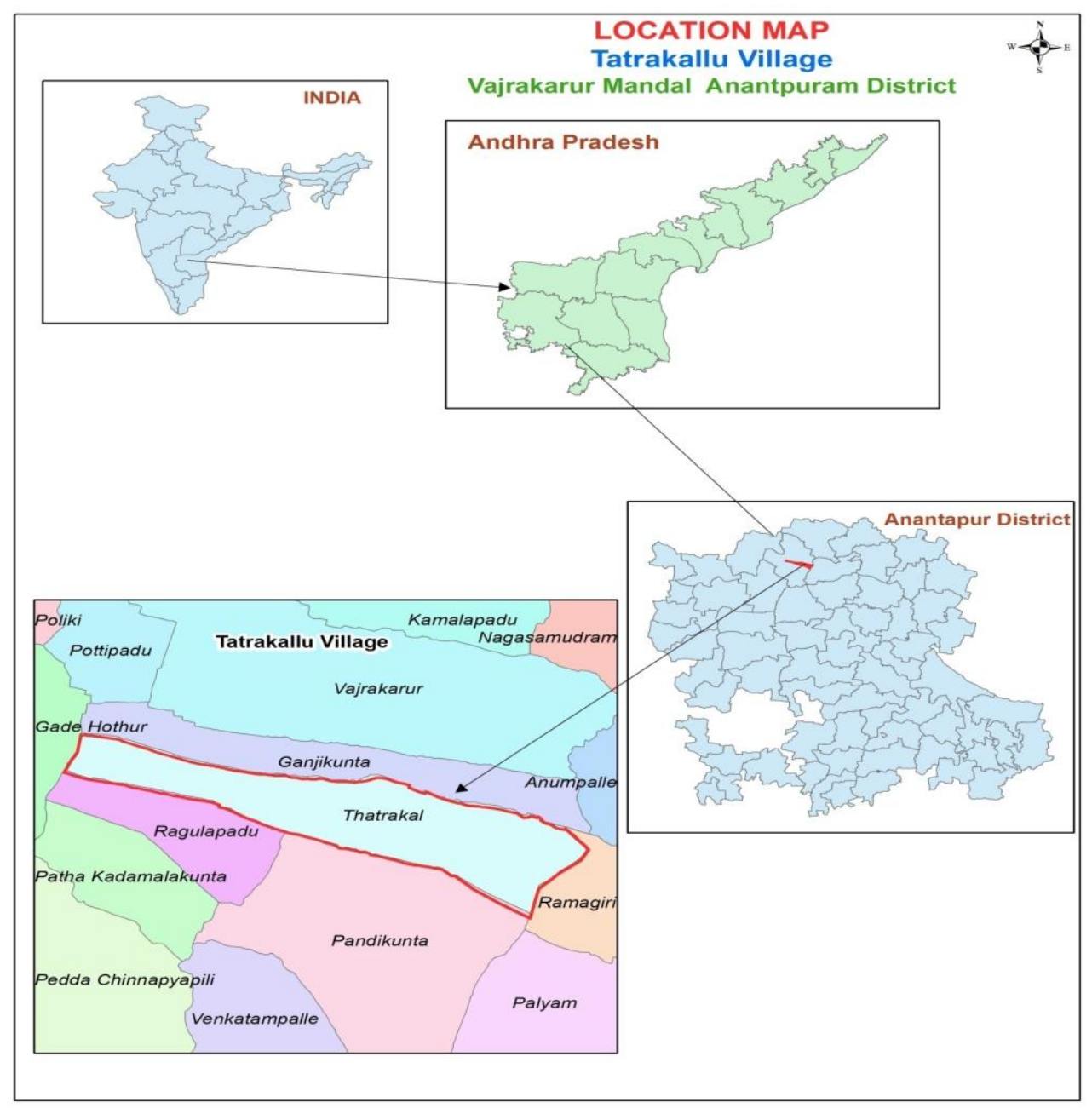

From the study, it can be concluded that, soils of Tatrakallu village in scarce rainfall zone of Andhra Pradesh are neutral to strongly alkaline with non-saline in nature. Alkaline soils in the study area need immediate attention for their management to arrest further degradation. Soil organic carbon content was low to medium.

Available $\mathrm{N}$ was low to medium, available $\mathrm{P}_{2} \mathrm{O}_{5}$ and $\mathrm{K}_{2} \mathrm{O}$ was low to high, and available $\mathrm{S}$ was deficient to sufficient. Regarding available micronutrients, zinc ( $\mathrm{Zn})$ and iron (Fe) were deficient to sufficient whereas $\mathrm{Cu}$ and $\mathrm{Mn}$ were almost sufficient in the soils. The fertility status of nutrients in study area revealed that, available $\mathrm{N}, \mathrm{S}, \mathrm{Zn}$ and $\mathrm{Fe}$ are important soil fertility constraints indicating their immediate attention for sustained crop production.

The deficient micronutrients need to be replenished to avoid the crops suffering from their deficiency and for optimum utilization of other nutrients.

\section{Acknowledgement}

The study is part of my Ph.D work under the control of Acharya N.G. Ranga Agricultural University (ANGRAU), Andhra Pradesh. The authors duly acknowledge the support. 


\section{References}

Basavaraju. D., Naidu, M.V.S., Ramavatharam, N., Venkaiah, K., Rao, G.R, and Reddy, K .S. 2005. Characterization, classification and evaluation of soils in Chandragiri mandal of Chittoor district, Andhra Pradesh. Agropedology. 15:55-62.

Foth, H.D. and Ellis, B.G. 1997. Soil Fertility, $2^{\text {nd }}$ Edison Lewis CRC Press LLC. USA $290 p$.

IFPRI. 2011. Global Food Policy Report. International Food Policy Research Institute, NW Washington, DC 20006 1002, USA.

Jackson, M.L. 1973. Soil Chemical Analysis. Oxford IBH Publishing House, Bombay. 38.

Kumar, K.S., Hegde, R., and Kumar, S.C.R. 2010. Characterization of soils of a micro-watershed in eastern dry zone of Karnataka. Agropedology. 20(2):182-188.

Kumar, R., Prasad, V.B and Rao, M.S. 2002. The morphology, clay mineralogy and taxonomy of some soil of Singarayakonda mandal in Prakasam district of Andhra Pradesh. The Andhra Agricultural Journal. 49: 237240.

Lindsay, W.L. and Norvell, W.A. 1978. Development of DTPA soil test for zinc, iron, manganese and copper. Soil Science Society of American Journal. 43:421-428.

Manoj Kumar, D. 2011 Characterization and classification of soils of a microwatershed on basalt parent rock in northern transition zone of Karnataka. M.Sc. (Ag) Thesis, University of Agricultural Sciences, Dharwad, Karnataka.

Nalina, C.N., Anilkumar, K.S., Shilpashree, K.G., Narendrababu, B., Sudhir, K.,
Natarajan, A. 2016. Inventory and mapping of land resources for land use planning through detail soil survey coupled with remote sensing and GIS techniques: a case study in Nagenahalli watershed, Doddaballapur Taluk, Bangalore rural district, India. International Journal of Current Microbiology and Applied Sciences. 6(8):314-331.

Nelson, D.W and Sommers, L.E. 1996. Total carbon, organic carbon, and organic matter. In Methods of Soil Analysis, Part 3. Chemical Methods (D.L. Sparks, Ed.), Madison, Wisconsin. 961-1010.

Olsen, S.R. and Sommers, L.E. 1982. Phosphorus. In Methods of Soil Analysis (A.L. Page et al., Eds.), Part 2, 2nd edition, Madison, Wisconsin. 403-430.

Patil, P.L., Kuligod, V.B., Gundlur, S.S., Jahnavi, K., Nagaral, I.N, Shikrashetti, P. 2016. Soil fertility mapping in Dindur sub-watershed of Karnataka for site specific recommendations. Journal of the Indian Society of Soil Science. 64 (4):381-390.

Patil, P.L., Radder, B.M., Patil, S.G., Aladakatti, Y.R., Meti, C.B, Khot, A.B. 2006. Response of maize to micronutrients and moisture regimes in Vertisols of Malaprabha Command, Karnataka. Journal of the Indian Society of Soil Science. 54:261-264.

Prabhavati, K., Dasog, G.S., Patil, P.L., Sahrawat, K.L., and Wani, S.P. 2015. Soil fertility mapping using GIS in three Agro-climatic zones of Belgaum district, Karnataka. Journal of the Indian Society of Soil Science. 63(2):173-180.

Ravi Kumar, M.A., Patil, P.L., Dasog, G.S. 2007. Mapping of nutrients status of 48A distributary of Malaprabha right bank command of Karnataka by GIS 
technique. II-Micro nutrients. Karnataka Journal of Agricultural Science. 20:738-740.

Reddy, K.S and Naidu, M.V.S. 2016. Characterization and classification of soils in semi-arid region of Chennur mandal in Kadapa district, Andhra Pradesh. Journal of the Indian Society of Soil Science. 64(3): 207-217.

Sathish, A., Ramachandrappa, B.K., Devarajappa, K., Savitha, M.S., Gowda, M.N.T and Prashanth, K.M. 2018. Assessment of Spatial variability in fertility status and nutrient recommendation in Alantha cluster villages, Ramanagara district, Karnataka using GIS. Journal of Indian Society of Soil Science. 66(2): 149-157.

Satish, S., Naidu, M.V.S., and Ramana, K. V. 2018. Soil fertility status in Brahmanakotkur watershed of Andhra Pradesh. International Journal of Chemical Studies. 6(5):2911-2915.

Satyavathi, P.L.A., and Reddy, M.S. 2004. Distribution of DTPA extractable micronutrients in soils of Telengana, Andhra Pradesh. Agropedology. 14:32-44.

Shankaraiah, M., Sreemannarayana, B., and Srinivasaraju, A. 2006. Studies on the status and distribution of sulphur in black soils (Vertisols) of Karimnagar district, Andhra Pradesh. Indian Journal of Dry land Agricultural ReseArch and Development. 21:7479.

Srikant, K.S., Patil, P.L., Dasog, G.S., and Gali, S.K. 2008. Mapping of available major nutrients of a micro-watershed in northern dry zone of Karnataka. Karnataka Journal of Agricultural Sciences. 21:391-395.

Subbiah, B.V, and Asija, C.L. 1956. A rapid procedure for the estimation of available nitrogen in soils. Current Science. 25:32.

UNCCD. 2011. Land and soil in the context of green economy for sustainable development, food security and poverty eradication. The submission of the UNCCD Secretarait to the preparatory process for Rio+20. http://www.uncsd2012.org/content/do cuments

Venkatesh, M.S., and Satynarayana, T. 1999. Sulphur fractions and $\mathrm{C}$ : $\mathrm{N}: \mathrm{S}$ relationship in oilseed growing Vertisols of North Karnataka. Journal of the Indian Society of Soil Science. 47:241-248.

Williams, C.H, and Steinbergs, A. 1959. Methods and Analysis of Soils, Plants, Water and Fertilizers FDCO, New Delhi. India. 58:133.

\section{How to cite this article:}

Sashikala, G., M.V.S Naidu, K.V Ramana, K.V. Nagamadhuri, A. Pratap Kumar Reddy and Sushakar, P. 2019. Soil Fertility Status in Tatrakallu Village of Andhra Pradesh for Site Specific Recommendations. Int.J.Curr.Microbiol.App.Sci. 8(06): 1016-1023. doi: https://doi.org/10.20546/ijcmas.2019.806.124 